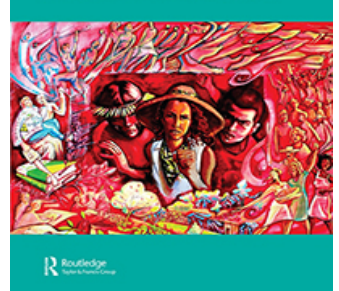

\title{
Farming is easy, becoming Brazilian is hard: North American soy farmers' social values of production, work and land in Soylandia
}

\section{Andrew Ofstehage}

To cite this article: Andrew Ofstehage (2016) Farming is easy, becoming Brazilian is hard: North American soy farmers' social values of production, work and land in Soylandia, The Journal of Peasant Studies, 43:2, 442-460, DOI: 10.1080/03066150.2014.998651

To link to this article: http://dx.doi.org/10.1080/03066150.2014.998651

曲 Published online: 26 Jun 2015.

Submit your article to this journal $[\pi$

ЏII Article views: 130

Q View related articles ๘

View Crossmark data ¿ 


\title{
Farming is easy, becoming Brazilian is hard: North American soy farmers' social values of production, work and land in Soylandia
}

\author{
Andrew Ofstehage (1)
}

\begin{abstract}
Since the late 1980s, North American farmers have been migrating to Brazil to produce soybeans and escape a general farm crisis in the United States. This paper analyzes their work, values, social relations and relations with the land in order to understand transnational farming and agrarian change from the perspective of transnational farmers. North Americans' migration to Brazil and soy production in Brazil can inform our understanding of the mechanisms of the soy boom and unpack the relative significance of social values at play in intensive, technified and financialized agriculture. It also provides an evocative perspective of the soy boom as it engages with issues of transnationalism, crisis, migration and change in business and farming practices. Using ethnographic data, this paper explores the intimate and emerging realities of agrarian change by detailing four elements of transnational farming migration, farm management, land use and work - through the narration of three farmers' career histories. These cases address the transformation of social values of work, land and social relations through the processes of migration and agrarian change. Farmers' work, it is found, emerges out of an entanglement of regulations, expertise, meanings of work and land, worker relations and the political economy of Brazil and the United States.
\end{abstract}

Keywords: agrarian change; values; work; transnational farmers; ethnography; soy; Brazil; United States

\section{Introduction}

Sitting in the shade on his Western Bahian soybean farm, John Hanson ${ }^{1}$ told me that his 'family has always farmed, [we] came from Ireland sometime in the 1800s and probably just always farmed'. The Hanson family is one of dozens ${ }^{2}$ of migrant US soy farm families in Western Bahia, Tocantins, Roraima, Goiás and Mato Grosso, Brazil. North American farmers came to Brazil in two waves, one stretching from 1988 to 1994 and another from 2000 to 2004. Generally, the first cleared native Cerrado to develop agricultural land, while the second purchased cleared and developed land. ${ }^{3}$ In Bahia, Brazilian and North Americans produce cotton, soy and corn, and several own cotton gins. North American narratives of migration and soy production in Brazil demonstrate how relative cultural

\footnotetext{
${ }^{1}$ All names in this paper are pseudonyms, in accordance with informed consent agreements.

${ }^{2}$ Estimated at 30 to 40 families, based on interviews with farmers and policy makers in Brazil.

${ }^{3}$ In addition to this group of Midwestern family farmers, a colony of 70 Mennonite families has farmed soybeans near Rio Verde, Goiás, since migrating from the United States in the late 1960s (Mello and Silva 2011).
} 
outsiders confront, adapt and co-opt the practices and values of soy farming in Brazil. These narratives add a transnational perspective on the motivations behind and in front of the international spread of the Brazil model of farming. These contributions are of particular interest in a moment of expansion of the Brazil Model of farming within Brazil and its spread, particularly to Sub-Saharan Africa. The phenomenon of US soy producers in Brazil provides an evocative perspective of the soy boom as it engages with issues of transnationalism, crisis, migration and change in business and farming practices.

An analysis of their migration bridges work that situates soy production in the political and economic histories of production (Hecht 2005; Oliveira 2013; Wolford 2008) with work that reveals the transformations of social relations and social practices within the field of soy production (Gudynas 2008; Peine 2010). I engage with both sets of work via a framework of social values of work to demonstrate the interconnected processes of farm crisis in the United States and the ways that North Americans transform, preserve and defend social relations, practices and values of production. I ask: what values, meanings, and practices of work, land, and production emerge through transnational soy commodity production? By taking seriously the social values and social context surrounding these global economic processes, I connect market dynamics with social values of soy production and link production dynamics in Brazil, primarily in the Cerrado, with agrarian transformation in North America.

\section{Soybeans in the Cerrado}

Soy production in the Cerrado of Mapitoba (Maranhão, Piauí, Tocantins and Bahia), a soy frontier region where the majority of US farmers have settled, is the product of government policy to incentivize agricultural expansion and intensification. The Brazilian State has mobilized soy to implement colonization and modernization projects in the Cerrado, replicating similar nationalist projects carried out in Amazônia (Hecht and Cockburn 2011) and Bolivia (Hecht 2005; Valdivia 2010).

State policies in Amazônia give legal title of unregistered lands to landless workers to reduce land grabbing and foreignization in that region. At the same time, the state incentivizes large-scale production in the Cerrado by implementing lower required Legal Reserves (20-35 percent in the Cerrado, depending on the state, compared to 80 percent in the Amazon ecosystem) and improving transportation infrastructure in the Cerrado region (Oliveira 2013). The greater exertion of state control over the Amazon, paired with the opening up of the Cerrado through policy and infrastructural incentives, 'actually result in greater [gross] deforestation and land concentration [in the Cerrado]' (Oliveira 2013, 279). State-sponsored research of soil amendment techniques and seed varieties, along with credit provisions, has incentivized large-scale soy production. This technocentric state support has increase production in the Cerrado while worsening distributional and procedural inequity (Wolford 2008).

\section{A Great Transformation?}

The Brazil Model of soy production, the assemblage of business and farming practices that make up the Brazilian agricultural system, is celebrated for providing work, modernizing agriculture in Brazil, increasing production and feeding the growing world population, all with limited direct governmental support (compared to US crop subsidies and European support for multifunctionalism), and little deforestation (Economist 2010). The characteristics of the model are no-till production, use of genetically modified organisms and a 
shift from managers of land to managers of labor; ${ }^{4}$ it also constitutes what Gudynas calls the 'Great Transformation of rural South America' (Gudynas 2008, 514). Recalling Polanyi's observations of the commodification and dehumanization of twentieth-century capitalism (Polanyi 2001), Gudynas frames the transformation of farm organization and agricultural work in Soylandia as a disembedding of production from social life and social relations.

The transformation of soy production in South America (see also Reboratti 2010 and Teubal 2006) entails a shift from integrated agricultural systems to monocultures, partial commodification to strong commodification, and local-based to export-oriented production. The farm itself is managed as a hierarchically organized and highly capitalized business (Gudynas 2008) in which the "classic image of poor farmers and rich ranchers is replaced by one of rural managers, most of them with university-level education, living away from the farm, and specialized in business management' (Gudynas 2008, 515).

The transformation enables large-scale soybean producers to see themselves as pioneers and heroes of market-oriented export agriculture and look to the market as legitimation of their work. Peine writes that soy farmers are

thought to be the unwitting victims of the corporate food regime, [but] they are inexorably incorporated into and therefore dependent on it...they become its agents, promoting its extension as a way to preserve their own livelihoods even as the total value of what they produce is expropriated by the companies that rule the regime. $(2009,59-60)$

Gudynas' analysis, supported and expanded by the work of Peine, deftly lays clear the stakes of agrarian transformation and the articulations of this change at the level of farm practice and business organization. However, while work, land and production are increasingly commoditized through the proliferation of the Brazil Model, farmers continue to articulate distinct values and meanings of production. US farmers conform to Gudynas' characterization in many aspects, but the transformation of their values and practices is neither homogenous nor complete. Neither are they able to impose North American values and practices unchallenged. Here I echo recent critiques of Polanyi's 'Great Transformation' (Mitchell 2008) which argue that the economy cannot be disembedded from social relations and cultural meanings. Farmers' practices and values of soy production emerge out of constant negotiation between themselves and Brazilian farmers, workers, governmental policies and soy agro-ecosystems in the Cerrado. I conceptualize the reproduction, transformation, and emergence of these different values and practices of soy production using David Graeber's 'anthropological theory of value'.

\section{Farming as work and work as socially valued action}

Midwestern farmers in Brazil possess highly technified machinery, operate within marketdriven institutions, and engage in a global soy commodity market. It may be attractive to view them as 'capital personified', their souls being the soul of capital (Marx 2012, 257), or to propose that, like Wall Street bankers, their values of work directly reflect the demands of the market (Ho 2009). However, research on large-scale producers throughout Latin America (Adams 2008; Adams 2010; Bobrow-Strain 2007; Eakin, Bausch, and Sweeney 2014; Hoelle 2012; Mackey 2011; Valdivia 2010) indicates that landowners

\footnotetext{
$\overline{{ }^{4} \text { See Goldfarb and Zoomers (2013) for an extensive analysis of the expansion of this technology fron- }}$ tier in Argentina.
} 
hold ethical and social values of work aloft as they defend their own work, often balancing agrarian and industrial regimes of value, other times focusing more completely on 'neoliberal' values of production. US farm families also struggle to uphold non-monetary agrarian dimensions of success, including daily work autonomy, opportunities for achievement and reward, and spiritual connections to nature and to agrarian work (Barlett 1993). Farmwork is subject to both capitalist and agrarian regimes of value. I propose that US farmers' work in Brazil entails a transformation toward a set of values and practices associated with the Brazil Model of farming, but also the reproduction of farmers' own identity, culture and work. I argue that the social values of soy production emerge out of economic and agro-ecological conditions and as well as contestations over the relative importance of action, or work.

Work, or action, is the subject of value realization and contestation; it is also a product of that negotiation (Graeber 2001). Value, as the importance of action, is subject to legitimation as actors defend their know-how and their work, thus entailing a process of 'people-making' in two senses (Graeber 2013). On one hand, actions establish one's status as a legitimate social actor, be it a good farmer, an upstanding community member or an innovative entrepreneur. On the other, actions, apparent in everyday practices (Certeau 2011) and everyday ethics (Brodwin 2012) of agriculture, re-make farmers as they tie emerging actions, such as managing labor or speaking Portuguese, to articulations of the self and community. Farmwork emerges out of the material realities of production - political economy and agro-ecology - but also out of social imaginations of what constitutes good and legitimate work.

This notion of value and action is useful in understanding the integration of the US farming community into Brazilian worlds of soy production. One can observe how the practices of the Brazil Model (i.e. hiring labor, use of genetically modified organisms and no-tillage) become valued as efficient, rational and economistic across diverse groups of producers. It also allows one to ask how farmers from different cultural or socio-economic classes re-affirm their identity and difference through practices and discourse on practices (see for example Ofstehage 2011, 2012). This is visible in how Brazilian and North American farmers adopt practices associated with the Brazil Model and then use these practices to define themselves as economically progressive farmers. It becomes apparent in how North Americans use practices that separate them from Brazilians to self-identify as bringing American values or know-how to Brazil.

Writing on elite landholders in Chiapas, Bobrow-Strain states that landowners' calculations of costs and benefits of defending their estates against Zapatistas 'were not the disembodied rational calculations of Homo economicus. Rather, they were painful struggles over identity in which uncertain landowners grappled with the upending of the once reliable categories of nature, race, development, good government, and masculinity' $(2007,208)$. This experience of embodied struggles, reflecting non-capitalocentric behavior (GibsonGraham 2006; Miller 2001; Mitchell 2008), defies liberal, rational calculations and emerges in other studies of elite landholders.

Ranchers in Acre, Brazil, for example, connect their migration from southern Brazil to family legacies of migration from Europe and to nationalist discourses on taming, colonizing and developing Amazonia. They also defend their work as contributing to national food security (Hoelle 2012). Brazilian landholders and soy producers in Bolivia also make claims on their work as development or improvement (see Li 2007); in the words of one farmer, 'We came with money, we put in technology, it was really a win-win relationship. We all win, the Brazilians won, Bolivia won, and the Bolivian producer won' (Mackey 2011, 20). Soy producers in Bolivia juxtapose themselves against the Morales government 
as moral compasses of capitalism (Valdivia 2010). Gaúcho farmers in Santarem, Brazil, explain their move to the Center-west as a response to high land prices in the South and increasing land concentration in Mato Grosso, but also refer to their roles as missionaries of modernity and highlight family histories of migration and farming (Adams 2010). Each of these cases demonstrates both economic and non-economic objectives. Profit sits alongside pursuit of individual and collective desires, pleasure, and freedom as objectives for landowners in Latin America.

\section{Methods}

I conducted 19 interviews with US soy producers who operate farms in Brazil, with the US Foreign Agriculture Service and with local crop advisors in Brazil. I conducted several daylong farm tours and attended get-togethers of the US community in Brazil, and recorded career history interviews and interviews centered on their everyday farming and social lives in Brazil. On farm visits, I recorded agricultural landscapes and practices that distinguished farmers' practices in Brazil - ranging from the mundane (soccer fields on the farm) to the more agriculturally significant (high-tech machinery, security fences and housing for workers). Research participants were identified through a literature review of newspaper articles on North American farmers in Brazil prior to research, and snowball sampling after arrival in Brazil. ${ }^{5}$

I present three farmers' career histories as integrated narratives in order to show the inter-relatedness of socio-economic processes in Brazil and the United States and to show the gradual transformation being done on farmers, even as they themselves transform practices and the land in Brazil. These career histories, chosen for their ability to represent difference and sameness among the research group, narrate personal moments in actors' lives that are indicative of both sameness among North American soy producers in Brazil and difference in farm practices, social relations and social values. In concert, the career histories tell a situated story of agrarian change (Colloredo-Mansfeld 2009). In presenting integrated realities, I hope to establish also the difficulty of interpreting any one of these farmers as a purely liberal subject. Each is caught up in multiple projects, some collective and some more personal. Two of the career histories follow North Americans in Brazil's Cerrado and a third career history follows a US farmer in Roraima.

I divide the remainder of this paper into two sections. First, I review the literature on a general farm crisis in the United States and an expanding commodity frontier in the MaPiToBa region of Brazil in order to show the inter-connectedness of these processes. Second, I analyze the social values of work that are produced and reproduced through transnational soy production.

\section{Twenty-first-century US farm crisis}

I conceptualize structural aspects of production alongside actors' social worlds of production through crisis. Crisis is a dynamic process in which 'particular sets of social relations, political connections and economic practices' link up with development interventions and forces of political economic change to construct post-crisis realities (Fraser, Fisher, and Arce 2013, 68). Crisis frames agrarian change in relation to both the big

\footnotetext{
${ }^{5}$ I presented myself primarily as a researcher interested in the role and everyday lives of US farmers in
} Brazil. 
battalions' of capital, state and land (Scott 1985), and improvisation, social values and community-making. It integrates cultural, ecological and economic phenomena and re-affirms that 'economic crises are ecological crises are cultural crises' (Escobar 2008, 14).

Studies on large-scale soy producers in South America reflect the dual process of crisis and frontier expansion. Southern Brazilian Gaúcho soy farmers in the Northern Brazilian city of Santarem, for example, explain their internal migration as a response to shortage of land in the South and highly consolidated farms in Mato Grosso (Adams 2010). Likewise, Gaúcho cattle ranchers in rural Acre, Brazil, explain their migration as a search for opportunity to expand land acreage, but also to continue ranching and migration legacies (Hoelle 2012). I place the work and migration of North Americans in a similar context crisis is not deterministic of their migration, but an understanding of their migration is impossible without an understanding of the social, ecological and economic conditions of farming in the United States.

The US farm crisis of the 1980s, or 'farm financial stress', precipitated from heavy debt loads, rapid declines in the value of farm land and other agricultural assets, low prices for many of the most important US agricultural commodities, and a somewhat heightened pace of voluntary and involuntary liquidation of assets (Buttel 1989). Farmers changed management styles, became part-time workers and engaged with government farm support, together entailing a clash of industrial and agrarian values (Barlett 1993; Dudley 2002). ${ }^{6}$ The agrarian crisis in the United States has continued into the twenty-first century in the form of higher farmland values, farm corporatization, farm consolidation and changing agricultural practices. These processes, in turn, have narrowed profit margins, increased dependency on finance markets, shifted expertise from agro-ecological knowledge to knowledge of high finance and reduced labor requirements (MacDonald, Korb, and Hoppe 2013).

\section{Inaccessibility of land}

Two factors have contributed to the decreasing accessibility of land for farmers, especially young farmers in the United States - rising farmland prices and consolidation of farmland under fewer entities. Since the farm crisis of the 1980s, land prices have risen from around USD 1000/acre to nearly USD 2000/acre (Nickerson et al. 2012). This average masks even higher farmland values in highly productive regions. Even poor-quality land in Indiana, as of the summer of 2013, sold for an average of USD 5750/acre (+14.7 percent from 2012), while average-quality land sold for USD 7446/acre, (+17.1 percent) and top-quality land sold for USD 9177/acre (+19.1 percent) (Dobbins and Cook 2013). Iowan farmland is similarly expensive, with the state average rising to USD 8296 in 2010. Iowan agricultural producers cited high commodity prices, low interest rates, cash/credit availability and lack of land availability as key factors in the rising cost of land (Duffy 2013).

As the price of farmland has increased, so has farm consolidation. Despite an increasing number of small farms, the average size of the US farm has increased from 589 acres per farm in 1982 to 1105 acres per farm in 2007. United States Department of Agriculture (USDA) researchers credit changing technology, changes in the organization of farms, and government policy for the changing make-up of US farms (MacDonald, Korb, and Hoppe 2013). Family owned and operated farm businesses dominate the agricultural

\footnotetext{
$\overline{{ }^{6} \mathrm{My} \text { own father experienced this crisis on our South Dakota farm as pressure to consolidate and }}$ narrow his production to a corn/soybean rotation, and as a community trauma. This experience and the general situation of my family's farm was shared with research subjects.
} 
landscape of the US, but the size of the farms comes with a shift toward reliance on hired labor, rented land and contracted services (MacDonald, Korb, and Hoppe 2013). In order to manage this new agrarian model, families have formalized their businesses as limited-liability companies (LLCs) and family or non-family corporations (O'Donoghue et al. 2011). ${ }^{7}$ As of 2007, 43 percent of US farm production originated on farms organized as partnerships or corporations, an increase of 9 percent from 1982 (O'Donoghue et al. 2011).

\section{Displacement of farmwork by technology}

The 1980s farm crisis changed the value and meaning of labor in which 'well-tended fields, hard work, and performing tasks 'in a timely manner' ceased to evoke praise (Barlett 1993, 238). With the introduction and widespread adoption of biotechnology, ${ }^{8}$ no-tillage cultivation and reduced chemical pesticide use, productivity has risen despite reductions in the use of labor and, as Midwestern farmers claim, 'made good farmers lazy and lazy farmers good'. ${ }^{9}$ Since 1982, operator labor has fallen by 40 percent and hired labor has fallen by 30 percent (MacDonald, Korb, and Hoppe 2013). The operator and spouse labor accounts for three fifths of labor on small farms, one half on medium-sized farms, and 11 percent on 'large farms - the remainder being hired labor' (MacDonald, Korb, and Hoppe 2013). Forty percent of US farmers worked off-farm for at least 200 days per working year; indeed, many rely on this labor for financial survival (MacDonald, Korb, and Hoppe 2013).

Increasing farmland prices have benefited landholders, new forms of business organization protect families (and investors) against risk, and new production practices allow producers to reduce labor and pursue part-time work; however, all of these processes raise barriers for young farmers to enter into production agriculture. Young farmers confront a post-1980s agricultural landscape in which land is inaccessible, technology displaces labor, and the outlook for small-scale family farms is dire. This landscape interconnects with the political economy (see Oliveira 2013) of Brazil to co-construct the migration of North American soy producers to Bahia and the emerging soy frontier of Mapitoba.

\section{The soy frontier of Mapitoba}

Restrictions to soy production in Amazônia and encouragement from public policies and infrastructural development have transformed the Brazilian Cerrado into a 'hotspot' of deforestation and soy production (Hecht 2005); it also serves as a haven for certain US farmers. In the soy frontier region of Mapitoba, low-biomass forests are being rapidly converted to soy production. Investors and soy producers have flocked to Mapitoba to seek out a large area of available land, low land prices compared to comparable agricultural production regions of the United States or Brazil, a reduced presence of environmentalists compared to Amazônia and a favorable infrastructural situation (Mondardo 2010). In Western Bahia, the site of most non-Mennonite US-owned soy farms, agricultural production increased from approximately $2.05 \mathrm{~km}^{2}$ in 1979 to $1615 \mathrm{~km}^{2}$ in 1986 , then to $5743 \mathrm{~km}^{2}$ in 2000 and to $7259 \mathrm{~km}^{2}$ in 2005, covering 55 percent of total land in that year (Brannstrom

\footnotetext{
${ }^{7}$ LLCs and corporations reduce economic risk by protecting non-business assets from liability, and generally reduce tax burden.

${ }^{8}$ Ninety percent of corn planted, 90 percent of cotton planted and 93 percent of soybeans planted in 2013 were genetically modified (USDA, National Agricultural Statistics Service 2013).

${ }^{9}$ Suggesting a leveling process and a shift away from agro-ecological expertise and in-field work.
} 
2009). The rapid influx of capital and 'agents of modernization' transformed the region from an isolated region economically based on low-density cattle ranching and shifting cultivation to one based on capitalist agriculture, provoking conflicts between capitalist farmers and peasant families (Diniz 1984). Mirroring Jason Moore's 'commodity frontier' analysis (Moore 2010a, 2010b), US farmers flee crisis in the United States; they help to consolidate a regional process of soy expansion and development in Mapitoba; they also, perhaps unknowingly, participate in a historical transformation of a region and the continuation of social conflict. In the following section, I analyze issues of migration, farm management, land use, and work and worker relations via three farmers' career histories. Narratives on migration illustrate the presence of crisis and hope in migration decisions. An analysis of their Brazilian farm management indicates US farmers turn to financial capital and the process of locating farm property. The final two sections on land use and workers illustrate the uneven spread of farming and business practices associated with the Brazil Model as US farmers 'become Brazilian', as well as farmers' legitimization of these practices.

\section{Migrating to Brazil: sleepless nights and National Geographic}

\section{Jacob and Paul Miller: the entrepreneurs}

Jacob Miller's family is descended from a German farmer who migrated to northwest Iowa in the nineteenth century; the family still owns the century farm. Jacob's father, Paul, inherited the homestead in the early 1970s, during the inflationary period, and continued to operate the farm until the 1990s. He now rents out the farm and manages his financial services and consulting business. Interested in other investment options, Paul took a Brazilian agricultural tour in 2001 and was promptly amazed by the extensive availability of flat land, although he reported that the soil was degraded and had a poor soil profile and was "nothing but Cerrado'. Jacob, then still in university, reported sleepless nights, saying,

I remember I couldn't sleep the first three nights 'cause I was so excited about it and you come from Iowa and you know, these 80 -acre ${ }^{10}$ fields and you come down here [Bahia] and you see everyone has these 1000-acre fields and you didn't even know stuff like that existed and you'd go home and explain it to people and they'd either think you're exaggerating or you know they don't believe you.

They witnessed the clearing of Cerrado and pasture, 'not much besides 10-foot trees and grassland', and were told that the site was near to a limestone quarry that would be useful for making the poor soils fertile. The two Iowans found the scope and scale impressive enough for them to suggest that someday Bahia could look like their home acreage. The tour operator informed them of the relatively cheap but 'unskilled' labor force in the region, and the family began to seriously consider purchasing land in Brazil.

\section{Kurt and Caleb Carter: the missionaries}

The Carter family came to Brazil in 1972 after Caleb Carter sold the Indiana farm to become a missionary in São Paulo and Paraná. His son Kurt stayed in Brazil until 1977 when, drawn

\footnotetext{
$\overline{{ }^{10} \text { In this paper I use both 'acres' and 'hectares' to describe area; my use of each term is determined by }}$ how each farmer referred to land, whether using the US measure (acres) or the Brazilian measure (hectares). For reference, a hectare is equal to 2.56 acres.
} 
by an interest in farming, he moved back to Indiana to work on his grandfather's farm and attend university. After 10 years in Indiana, Caleb asked Kurt to leave the Indiana farm for a few years to help out with the expanding missionary organization. Kurt departed Indiana with his wife and then-10-month-old son Brad and worked in the missionary's accounting department. This work provided experience with Brazilian business practices and international money transfers that would later prove invaluable. After seven years working for the missionary, the young family moved to central Brazil to fill a perceived 'spiritual burden for farmers in central Brazil [Mato Grosso], [where] there's no church, or bible study or anything' and also as a means of re-connecting with agricultural production. According to Kurt's son Brad Carter, and current manager on the family farm, 'my parents made the decision from that standpoint to go to central Brazil, and agriculture was a little bit of a secondary question. They had to do something to be there in the community'.

\section{John and David Hanson: the manager and the farmer}

David Hanson grew up on a large family farm operated by his father, uncle and grandfather, and he 'never had any doubt he was going to farm'. He was studying business at a state university when, drawn by press coverage on the soy boom and personal connections to tour operators, his father and uncle went on a short agricultural tour in Brazil's Cerrado. Months later, they went on a second, longer tour. David's father and uncle saw Brazil as a means of acquiring more land to expand and maintain the family farm as well as provide more on-farm work opportunities to the wider family. David, on the other hand, saw it as a means of starting to farm straight out of college without heavy capital investment to buy land in the Midwest or waiting to take a more central role in the family farm. He also wanted to farm without depending on gifts of land and machinery from the family.

\section{First impressions of Brazil and expressions of crisis}

The first experience for most North American farmers in Brazil regularly begins with an agricultural tour intended to confirm the whispers of farming opportunities in Brazil. Farmers' tour experience highlight is often the sight of felling trees and extensive, productive land. The sight of felling trees simultaneously reminds them of the clearing of native prairies in the Midwest and highlights the transition from wasteland to productivity occurring in Brazil. The main objective for purchasing land in Bahia is mixed. Some do so to sustain the family farm, others to capture a seemingly ripe and easy profit, and, in the Carters' exceptional case, to conduct missionary work. For most farmers, Brazil serves as a solution to the rising costs of production in the United States and the increasing difficulty of finding land for farm expansion. There is also a sense of adventurism one farmer even reported that it felt like he was living in the pages of National Geographic.

A sense of crisis is present in all three narratives - the Millers' crisis of farm profitability in Iowa, the Carters' spiritual crisis and early transition from agriculture and the Hansons' crisis of land scarcity. As we see in the Millers' and Hansons' narratives, the migration of US producers to Brazil cannot be disentangled from conditions of opportunity and threat in the United States. The Millers respond directly to the unprofitability of farming in the Midwest, while the Hansons respond to a more complex situation in which it is not only profitability, but also a way of life that is threatened. 


\section{Farm management: accumulating land and courting financiers}

The Millers

In 2001, the family pulled together 'a few million [dollars]' through a private placement offering, a non-public funding stream, and the family purchased land from another North American in Western Bahia. A private placement offering requires that investors must have a prior relationship with the company; thus, the family attracted interest from business partners, nearby farmers and other colleagues. They also raised capital by selling Iowa land at USD 3100/acre and purchasing Bahian land at USD 800/acre. David Miller's son Jacob packed his bags and, without speaking Portuguese or having much farming experience of his own, relocated to Brazil. The Miller family purchased land from a fellow North American near Luis Eduardo Magalhães, Bahia, who then managed the farm. It became operational in 2004. After some management issues in the early years, they turned the business over to Jacob. Today, the farm employs 90 farmworkers, 60 workers for the cotton gin, 10 office employees, an agronomist and an operations manager. They cultivate 4000 hectares of soybeans and 3000 hectares of cotton, and own 9000 hectares of Cerrado in Legal Reserve. Looking ahead, the family has taken on an international funder as their major investor. The long-term plans of the funder are to package the farm with agricultural production investments in Argentina and South Africa to be sold as private shares on the stock exchange. Jacob and Paul are currently sitting on the farm's executive board with plans for Jacob to remain in his position and possibly translate his experience into work as an analyst or consultant.

\section{The Carters}

As a way of financing this mission, and re-engaging with the agrarian life, Kurt courted like-minded investors, driven by missionary objectives as well as capital accumulation, to begin a soybean farm in Mato Grosso - some investors are also missionaries, and many are farmers. The farm grew slowly and the family witnessed, and implicitly contributed to, the tremendous growth of the region, going from having 'nothing, no bank or phone lines' to producing $1,000,000$ metric tons of soy annually. The family continued to do missionary work and grow the farm until 2001, when they perceived an economic and spiritual opportunity in the North of Brazil. Land prices were rising in Mato Grosso while prices in Roraima remained low. Roraima also had extensive infrastructure and expected market opportunities with Venezuela. They sold the Mato Grosso farm for 40 percent over their expected market price. However, the move came with difficulties. Land prices in Roraima at the time that the family decided to move (2001) were 40 reals, then increased to 100 reals by 2003 , and then rose by another 800 reals in the next 18 months. To make this turn of events worse, poor weather conditions in Roraima placed a stress on farming, as I will discuss below.

\section{The Hansons}

The Hanson family purchased 4400 acres in 2001, not including Legal Reserve, for a tenth of the price of Midwest farmland. Unlike most US farmers in Brazil, the Hansons selffunded their move to Brazil using capital from their Midwest farm. This purchased land was cleared, but not yet completely 'developed'. At the time, David spoke no Portuguese, and had relatively poor knowledge of the local agro-ecological conditions. Through the years he has learned the language informally and developed a cropping rotation that is less focused on soy and more dedicated to cotton - a rotation that more closely resembles 
that of Brazilian producers in the region. At the time of research (2012), the farm had 30,000 acres of production land, 4000 of which was cleared by the business; the remainder was cleared prior to being purchased. These 30,000 acres are in a rotation of corn, soy and cotton, with the relative mix of the three crops changing year to year with the changes in commodity markets. In addition to their own land, they manage a sizeable acreage for a US investment firm.

\section{Mirrors of Midwest farm corporatization}

Financing for US farms in Brazil often come through personal contacts, much in the way that investors for ethanol plants in the Midwest are often local farmers. For farmers who distrust the stock market or other investment funds, ethanol plants and international production groups organized into limited liability companies offer an expected return on investment, but also a measure of legibility as a less abstract, more personal investment. Nearly all US soy producers in Brazil form corporate bodies such as LLCs or corporations, or are moving towards that model. This reflects the nature of large-scale production in Brazil as much as the changing landscape of family farm corporatization in the United States (MacDonald, Korb, and Hoppe 2013). Farm investments also mirror global trends of farm financialization (Fairbairn 2014) in which financial motives, markets, actors and institutions take on a larger role in farm production and capitalization (Epstein 2005). Through the own-operate model of farm financialization, land is both a productive asset and a speculative one, meaning that while farmers do intend to profit annually from sales of their harvest, they also expect to sell their developed land at a profit (Fairbairn 2014).

\section{Uses and visions of the land: farming is easy}

The Millers

Portuguese is not among the challenges of farming in Brazil for Jacob Miller; he has acquired more than a working knowledge of the language. Neither is it the actual process of farming; he hired consultants and learned more appropriate agricultural techniques (e.g. implementing no-till farming systems on some of his fields and adopting a cropping rotation that better suits the soils and the crops). Rather, the most difficult element it is the process of making land 'productive'. 'The clearing', he said, 'is really the easy part, it's the development that's the hard part, it takes a lot of time, it's an expensive process'. Once workers clear the land, one adds lime, gypsum, and phosphorus to increase the $\mathrm{pH}$ level of the soil; thereafter, one continues to build the soil with mineral amendments and no-tillage farming. Development of the land, he said, 'takes years, it's not even a matter of just adding fertilizer, it takes years to build up the fertility and soils and, and build 'em up to the point where you produce optimal yields so we kinda learned about that the hard way'.

The Millers faced challenges in both disease pressure management and producing cotton. Although fungicides are rarely used in Iowa, in Bahia they typically apply insecticides and fungicides to soybean five times annually. For cotton they applied 17 rounds of insecticides and fungicides, using 41 different insecticides. Cotton production was entirely new to the Millers and required a large capital investment for machinery and for a cotton gin, although not all farmers in Bahia own their own gin. 


\title{
The Carters
}

Of the North Americans I interviewed, the Carters had the greatest difficulties with the actual production process. In their first year in Roraima, floods prevented most of their planting and the little that they could plant was seeded too late to fully mature. Adding to this difficulty, a 15-day drought during a key moment in the maturation process prevented seeds from fully filling out. For what was planted, they harvested 60 percent of the expected yield. The year after, the family again experienced a series of untimely dry periods and heavy rain periods, which prevented planting of some acres, forced them to plant later than hoped, or forced them to replant hundreds of acres. At the time of research they were expecting 50 percent of expected yield. This experience has led the Carters to consider moving to a more corporate style of farm organization and to consider merger options in order to reduce personal financial risk.

\section{The Hansons}

When asked about the region prior to their settlement, David responded that before they came there was nothing: it was unproductive, had no decent roads and no real infrastructure. Part of the effect of their conversion from Cerrado to farmland was to contribute to the agrarian and economic development of the region. The Hansons developed the land by adding large amounts of lime and gypsum the first year and then supplementing with phosphate, potash, magnesium, nitrogen and lime thereafter.

Although production does not even register in David's list of top challenges of producing soy in Brazil, the regulations on land use do (along with uncertainty, lying, capital, weather, theft and culture). Among the most intrusive, according to David and other farmers, is that all cotton and soybean plants must be removed from agricultural fields by September 1 of every year; the cost of infraction is a USD 15,000 fine. This law is meant to reduce disease, pest and fungal pressure on crops by removing hosts from the agro-ecology, but David sees this as a prominent example of government intrusion on farmers' day-to-day operations. ${ }^{11}$ Seen as less intrusive but no less costly is the required 20 percent Cerrado Legal Reserve in Bahia, intended to preserve native Cerrado land.

\section{From waste to value}

North Americans' productivist agrarian visions of Cerrado land reflect this statement below, which in turn reflects the research and work of Philip Warnken (1999):

\begin{abstract}
The Cerrado area has been defined as a wasteland with stunted twisted trees. The Cerrados are not rainforests. The soils of the Cerrado are highly acidic, saturated with aluminum, deficient in phosphorous [sic] and have low water-holding capacity .... It is clear that there is a potential for large increases in crop production in the Cerrados. (McVey, Baumel, and Wisner 2000, emphasis added)
\end{abstract}

North Americans in Brazil repeat the narrative of bringing unproductive land into the productive economic sphere, a narrative that is common among soy producers in Bahia and other soy frontier regions of Brazil and Bolivia. They also repeat the narrative that is

\footnotetext{
${ }^{11}$ Much like farmers' resistance to the United States Environmental Protection Agency (EPA) control of air pollution and non-point source pollution in the US Midwest (Nixon 2014).
} 
alluded to in the quote above, that the Cerrado is neither nature worth preserving (as the Amazon is), nor fertile land demanding to produce. US farmers in the Brazilian Cerrado re-configure meanings of the land as modern or traditional, mirroring agrarian change elsewhere in Brazil (Sauer 2012), and echoing agro-industrialist discourse in the soy frontier of lowland Bolivia where low-biomass forests are less valued (despite high ecological value) and are 'easily, and relatively cheaply, cleared with heavy machinery' (Hecht 2005, 278). The construction of the Cerrado and other 'non-productive' lands mirrors statements by Brazilian immigrant soy producers in Paraguay (Albuquerque 2005) and reflects what Gidwany and Reddy refer to as the corollary of value - waste (2011). Opening up production frontiers, settling where there was 'nothing' and juxtaposing the Cerrado against Amazonia constructs non-productive land as waste - as the other of capitalist value. This in turn lends legitimacy and even heroism to large-scale soy production as well as forging a link to European ancestors who opened up the plains by homesteading.

The Cerrado is a wasteland, neither productive nor pristine, which, through hard work, can be made productive. The experience does differ between those who purchased native Cerrado land and those who purchased cleared or developed land. Those who cleared native land often expressed special pride in that action. This development of land is also frequently tied to the so-called development of Luis Eduardo Magalhães as seen in the towns' growth, the expansion of infrastructure and lowered unemployment. The town has grown from little more than a truck stop in the early 1990s to the 'Capital of Agribusiness' and a clean and orderly refuge for Southern Brazilian gaúchos in Bahia (Brannstrom and Brandão 2012). The Cerrado itself is frequently seen as something that does not require protection. It is something that should be excluded from discussion of wildlife conservation, despite the rich biodiversity that is present.

Although the 'development' of land can take years and farmers are under threat of crop pests, drought and flooding, few farmers include production practices among the most difficult aspects of producing soybeans in Brazil. As I will show in the following section, the nature of agricultural work shifts from work in the field to work in the office. Farm work by US farmers is generally limited to decisions on which seed variety to plant, whether to use no-tillage or when to spray a field - and these decisions are made with support from farm managers and agronomists. Farmers have experience with soy production and general farm management, but depend on local expertise, at least in their early years in Brazil, for producing cotton and responding to higher pest pressure in Brazil. While North Americans perceive the land as a wasteland in need of development, they are able to outsource the management of the land to local agronomists and farm managers, leaving the management of workers as the primary difficulty.

\section{Work and workers: becoming Brazilian is hard}

\section{The Millers}

Jacob's biggest difficulties are labor regulations and managing labor. Workers have "no skill and no training' and, according to him, they are coming from Southern Bahia and some have backgrounds in small-scale agriculture, but little experience with large-scale soy production or high technology machinery. On labor laws, he said,

it's not very, it's not fair for the employers, it's not practical ... I can understand it to a certain extent 'cause I think, there is a huge index, a difference between rich and poor and the rich do, or have a history of exploiting the poor in Brazil, but I don't know, it's just. But it's unfair to those that are trying to do what they can. 
Partially for this reason, the pushback from workers and labor laws, Jacob has dismissed previous concern for providing work and training for Brazilians; several farmers claimed an intent to bring jobs and opportunities to Brazilian workers until finding out that workers in Brazil had the backing of relatively strong labor laws and the farmworker federation. Recalling Mauss' theory of the gift, the apparent rejection of their job opportunities as gifts, farmers were somewhat offended and felt liberated from responsibility (Mauss 2000). Jacob perceives his role and the role of North Americans in general in the development of Brazil by saying, 'I think we've added, just, added to the community just from the fact that we pay our bills on time and conduct ourselves in a serious business-like manner [compared to Brazilian farmers].' The statement is at once less grandiose than the Santarem Gaúchos' claim to be 'missionaries of modernity' (Adams 2010) and less interested.

\section{The Carters}

The Carters chose to invest in long-term employee relationships. The family pays over market price for labor with the understanding that they expect long-term employment. They employ a foreman who manages the farm, one or two operators and seasonal help, a huge difference in total numbers compared to the typical Brazilian farmer. Brad, the youngest active member of the family, also mentioned that receiving payment in sacks of soy, what other North Americans often deride as bartering, is a way of engaging with the local farming community, and rather than a sign of backward business practice, an indication of real farming experience in Brazil. The Millers employ what Brad calls objectivedriven management, meaning that they intend and are required by investors to produce an economic profit, but that their management decisions are driven by an interest in treating workers well and being stewards of the land.

\section{The Hansons}

The Hansons' farm employs 11 managers and 165 workers; the work crew is cut to 14 workers in the off-season. The workers labor in teams such as soil fertility, harvesting and public relations, live in on-farm housing and typically leave the farm once every two weeks for three days. The workers represent one of David's greatest frustrations. David explains that Bahia isn't a traditional agricultural region and so workers aren't used to the odd hours and the realities of agrarian production. In his eyes, they are uneducated, untrained and often lazy. Compounding this perceived shortcoming of Brazilian agriculture are the labor laws. Labor laws, which regulate firing of workers, housing requirements and workdays, are seen as both intrusive and as superfluous. In response, David has worked around labor by adopting new technologies to replace labor force and reduce the risk of offending labor laws. He has also hired a public relations (PR) firm and a team of lawyers. David compares the current situation with the situation prior to the arrival of large-scale agriculture, saying: "when we came down it was commonplace for employees ... to live in plastic tents, you know, out in the Cerrado ... and now you can get a fine if you don't have the right brand of fire retardant'.

For David and his family, the farm has many different objectives. For David, the role of Americans is to bring some degree of rationality or business principles to Brazil. The main difference between North Americans and Brazilians, he says, is that Brazilians have a higher level of debt and more of a penchant to barter. What David brings is an understanding of the market and business principles. The immediate objective of the farm, however, is to function as a business and to make an economic profit as well as serve as a means for him 
to stay involved in agriculture. For the older generation, the farm expansion provides an opportunity for nieces and nephews, sons and daughters to find on-farm employment and to continue to strengthen the family farm. One of David's struggles in this regard is to encourage the older generation to see the value of working in the office serving business needs rather than driving a tractor in the field. For David, farming is not about sitting in a tractor; it's a business to be managed.

\section{Irrational regulations and lazy workers}

Section 31.23.5.1 of Brazil's regulatory laws of agricultural work is the target of many North American farmers' contempt: 'Worker housing must: have beds with mattresses, separated by at least one meter; when bunk beds are used must be limited to two beds in height, and have at least 110 centimeters in height between bunk beds' (Moraes 2013, translation by author). For North Americans like David and Jacob, rules like these are both overly constrictive and illogical, opinions that are repeated by Brazilian farmers in the regions. Others, like Brad Carter, see these restrictions as well as restrictions on firing/hiring of employees as forms of protection that are difficult to deal with, but valid. Despite many complaints about Brazilian regulations and the relative strength of the union of rural workers, few US farmers participate in negotiations between farmers and rural worker unions. Most avoid political involvement altogether. For example, while many Brazilian and some US farmers supported a national farmers' protest in June 2005, several US farmers openly derided the protest during interviews.

The mixed feelings of workers can be summed up by one farmer's statement that landless workers are thieves who try to get something for nothing, but at the same time admitted that were he in their situation he would participate in land occupations. The portrayal of farmworkers, especially Baianos, as quick to take advantage is widespread among both US and Brazilian farmers. Several farmers claimed an intent to bring jobs and opportunities to Brazilian workers, until finding out that workers in Brazil had the backing of relatively strong labor laws and the farmworker federation. However, not all farmers expressed such aversion towards Brazilian workers. Almost universally, interviewees reported that becoming a farm manager and getting used to working with Brazilians was the most difficult part of farming in Brazil. One reported that he thought 'learning plant names, insect names, learning to farm here' would be hard, but 'that's easy. Crop scouts, farmworkers know everything here. They tell you all you need to know, [they] know how to operate machinery'. The difficult part is becoming a manager.

In becoming a manager of labor rather than a manager of land, most North Americans are taking steps towards the Brazilian model of farm management as elaborated by Gudynas. This role allows many North Americans to claim that farming is easy in Brazil, it's getting used to Brazilian culture and regulations that are difficult. Farmers sit in tractors only rarely, and then only for agricultural tours or ethnographic interviews. Most of their time is spent in an office ordering delivery of inputs, securing sale contracts and meeting with farm managers. In the Hanson family, this has led to conflicting ideas of what a good farmer should do, the older generation preferring to be in a tractor demonstrating their hard work and technical skill, the younger generation demonstrating their business savvy from the office. Several younger farmers mentioned that this management style is one element of Brazilian agriculture that they would implement on farms in the Midwest. However, as we seen in all three narratives, there are elements of other visions of agrarian development that persist. The older generation on the Hanson farm still long for time in the 
tractor, the Miller family proposes that they can introduce US models of accounting into Brazil and the Carters seek out objective-driven worker relations.

\section{Conclusion}

Large-scale farmers struggle between a degree of autonomy (or freedom) and power. I use the concept of value as the importance of action to connect narrative of the soy boom as political phenomenon and cultural phenomenon by proposing that their migration to Brazil is a decision based on a confluence of material realities of soy production in Brazil, crisis in the United States, and personal and collective values and identities of work. In addition to this, new values are emerging as farmers engage with local forms of production, local actors, Brazilian culture and Brazilian legal regulations, and as they take on new roles as transnational farmers and as managers of labor.

While I was researching in Western Bahia, interviewees frequently turned my questions on agricultural practice and landscape transformation around on me to say that farming is easy in Brazil, it's getting used to Brazil that's difficult; or, as one North American caricatured his fellow migrants in an echo of a long-standing Brazilian joke, 'they say Brazil is great except for the Brazilians'. Farmers point to stories of North Americans who came to Brazil as fully competent farmers, but quickly went bankrupt due to worker conflicts, misunderstanding of labor or environmental regulations, or simply because they failed to adjust to the way things were done in Brazil. Patience, they said, is the key trait of a successful farmer in Brazil, next to rationality. The North Americans' recognition of the difficult process of becoming good Brazilian farmers, dismissive as it may be, reveals the importance of understanding the lived-in realities of the soy boom.

North American farmers bring with them collective and personal meanings of land, production and good farming. These meanings and imaginaries are mobilized to legitimize, even celebrate, their work in Brazil. Their very presence in Brazil is rarely explained by economistic language itself, but also through pursuit of good work (be it evangelical, entrepreneurial or agricultural) and the survival of family farming legacies. In looking at these non-economistic forms, globalization, through its articulation in the soy boom, can become less abstract and possibly less indisputable (Cravey 2003).

This ethnographic data finds that North American farmers in Brazil, like their elite landholding counterparts in Chiapas, Bolivia and Santarem, are working for more than economic profit, and their work is unfolding in relation with (not in domination over) land, workers, political economy and crisis. North American farmers remain neither fully autonomous in their engagement with soy production nor powerless against the forces of agrarian change; rather, they are semi-autonomous as their work emerges out of an entanglement of regulations, expertise, meanings of work and land, worker relations and political economy. For North Americans, then, producing soybeans in Brazil has many faces - it is the end of the US family farm and its continuation; it is an escape from the conditions of production in the US and their reproduction; it is production for the market and the making of people.

\section{Acknowledgements}

The author would like to thank Rudolf Colloredo-Mansfeld, Arturo Escobar, Gabriela Valdivia, Elizabeth Havice and Caela O'Connell for comments, and Susanna Hecht and Gustavo Oliveira for organizing this collection. Thanks also to Jun Borras and two anonymous reviewers for their comments. This research would not have been possible without funding from the Tinker Foundation and the Halperin Memorial Fund. 


\section{ORCID}

Andrew Ofstehage (D) http://orcid.org/0000-0002-4502-364X

\section{References}

Adams, R. 2008. Large-scale mechanized soybean farmers in Amazônia: New ways of experiencing land. Culture and Agriculture 30: 32-7.

Adams, R. 2010. Elite Landowners In Santarém: Ranchers, Gaúchos And The Arrival Of Soybeans In The Amazon. PhD diss, Indiana University.

Albuquerque, J.L.C. 2005. Campesinos Paraguayos y Brasiguayos en la frontera este del Paraguay. In Enclave sojero: merma de soberania y pobreza, 149-82. Asunción: Centro de estúdios rurales interdisciplinares.

Barlett, P.F. 1993. American dreams, rural realities: Family farms in Crisis. Chapel Hill: The University of North Carolina Press.

Bobrow-Strain, A. 2007. Intimate enemies: Landowners, power, and violence in Chiapas. Durham, NC: Duke University Press Books.

Brannstrom, C. 2009. South America's neoliberal agricultural frontiers: Places of environmental sacrifice or conservation opportunity. AMBIO: A Journal of the Human Environment 38, no. 3 : $141-9$.

Brannstrom, C., and P.R.B. Brandão. 2012. Two hundred hectares of good business: Brazilian agriculture in a themed space. Geographical Review 102, no. 4: 465-85.

Brodwin, P. 2012. Everyday ethics: Voices from the front line of community psychiatry. Berkeley: University of California Press.

Buttel, F.H. 1989. The US farm crisis and the restructuring of American agriculture: Domestic and international dimensions. In The International Farm Crisis, 46-83. New York: St. Martin's Press.

Certeau, M. de. 2011. The practice of everyday life. Berkeley: University of California Press.

Colloredo-Mansfeld, R. 2009. Fighting like a community: Andean civil society in an Era of Indian uprisings. Chicago: University of Chicago Press.

Cravey, A.J. 2003. Toque una Ranchera, Por Favor. Antipode 35, no. 3: 603-21.

Diniz, J.A.F. 1984. Modernização e conflicto na fronteira ocidental do Nordeste. Revista GeoNordeste 1, no. 1: $12-20$.

Dobbins, C., and K. Cook. 2013. Purdue Agricultural Economics Report (August 2013). West Lafayette, IN: Purdue University. https://www.agecon.purdue.edu/extension/pubs/paer/pdf/ PAER8_2013.pdf (accessed September 16, 2013).

Dudley, K.M. 2002. Debt and dispossession: Farm loss in America's heartland. Chicago: University of Chicago Press.

Duffy, M. 2013. 2012 Farmland Value Survey (No. File C2-70). Ames, IA: Iowa State University. http://www.extension.iastate.edu/agdm/wholefarm/pdf/c2-70.pdf (accessed September 1, 2013).

Eakin, H., J.C. Bausch, and S. Sweeney. 2014. Agrarian winners of neoliberal reform: The 'Maize Boom' of Sinaloa, Mexico. Journal of Agrarian Change 14, no. 1: 26-51.

Economist. 2010. The Miracle of the Cerrado. The Economist, 08/28/2010 Print Edition.

Epstein, G. 2005. Introduction: Financialization and the world economy. In Financialization and the world economy, ed. G. Epstein, 3-16. Northampton: Edward Elgar.

Escobar, A. 2008. Territories of difference: Place, movements, life, redes. Durham: Duke University Press.

Fairbairn, M. 2014. 'Like gold with yield': Evolving intersections between farmland and finance. Journal of Peasant Studies 41, no. 5: 777-95.

Fraser, J., E. Fisher, and A. Arce. 2013. Reframing 'crisis' in fair trade coffee production: Trajectories of agrarian change in Nicaragua. Journal of Agrarian Change 14, no. 1: 52-73.

Gibson-Graham, J.K. 2006. A postcapitalist politics. Minneapolis: University of Minnesota Press.

Gidwani, V., and R.N. Reddy. 2011. The afterlives of 'waste': Notes from India for a minor history of capitalist surplus. Antipode 43, no. 5: 1625-58.

Goldfarb, L., and A. Zoomers. 2013. The drivers behind the rapid expansion of genetically modified soya production into the Chaco region of Argentina. In Biofuels - Economy, environment and sustainability, ed. Z. Fang. Rijeka, Croatia: InTech: 73-95.

Graeber, D. 2001. Toward an anthropological theory of value: The false coin of our own dreams. New York: Palgrave Macmillan. 
Graeber, D. 2013. It is value that brings universes into being. HAU: Journal of Ethnographic Theory 3, no. 2: 219-43.

Gudynas, E. 2008. The new bonfire of vanities: Soybean cultivation and globalization in South America. Development 51, no. 4: 512-8.

Hecht, S.B. 2005. Soybeans, Development and conservation on the Amazon Frontier. Development and Change 36, no. 2: 375-404.

Hecht, S.B., and A. Cockburn. 2011. The fate of the forest: Developers, destroyers, and defenders of the Amazon. Chicago: University Of Chicago Press.

Ho, K. 2009. Liquidated: An ethnography of wall street. Durham: Duke University Press.

Hoelle, J. 2012. Black hats and smooth hands: Elite status, environmentalism, and work among the ranchers of Acre, Brazil. Anthropology of Work Review 33, no. 2: 60-72.

Li, T.M. 2007. The will to improve: Governmentality, development, and the practice of politics. Durham: Duke University Press Books.

MacDonald, J.M., P. Korb, and R.A. Hoppe. 2013. Economic Research Report Number 152: Farm Size and the Organization of U.S. Crop Farming (Economic Research Report No. 152). USDA Economic Research Service. http://www.ers.usda.gov/publications/err-economicresearch-report/err152/report-summary.aspx\#.UjSslWR4bfU (accessed December 10, 2013).

Mackey, L. 2011. Legitimating Foreignization in Bolivia: Brazilian Agriculture and the Relations of Conflict and Consent in Santa Cruz, Paper presented at the International Conferernce on Global Land Grabbing. 6-8 April, Brighton: university of Sussex. http://www.iss.nl/fileadmin/ASSETS/ iss/Documents/Conference_papers/LDPI/23_Lee_Mackey.pdf (accessed September 20, 2011).

Marx, K. 2012. Capital, volume one: A critique of political economy. Mineola, NY: Courier Dover Publications.

Mauss, M. 2000. The gift: The form and reason for exchange in Archaic societies. New York: W. W. Norton and Company.

McVey, M., P. Baumel, and B. Wisner. 2000. Brazilian soybeans - What is the potential? Ames, IA: Iowa State University. http://www.extension.iastate.edu/agdm/articles/others/McVOct00.html (accessed November 1, 2012).

Mello, H.A.B. de, and S.D.S. Silva. 2011. Revisitando Contextos Bilíngues em Goiás. Dossiê Imigrantes no. 10: 11-39.

Miller, D. 2001. Turning Callon the right way up. Economy and Society 31, no. 2: 218-33.

Mitchell, T. 2008. Rethinking economy. Geoforum 39, no. 3: 1116-21.

Mondardo, M.L. 2010. A 'territorialização' do agronegócio globalizado em Barreiras - BA: migração sulista, reestruturação produtiva e contradições sócio-territoriais. Revista NERA 13, no. 17: $112-30$.

Moore, J.W. 2010a. 'Amsterdam is standing on Norway'Part I: The alchemy of capital, empire and nature in the diaspora of silver, 1545-1648. Journal of Agrarian Change 10, no. 1: 33-68.

Moore, J.W. 2010b. 'Amsterdam is standing on Norway'Part II: The global North Atlantic in the ecological revolution of the long seventeenth century. Journal of Agrarian Change 10, no. 2: 188-227.

Moraes, G. 2013. Legislação de Segurança e Saúde no Trabalho 2013 - 10a Edição. Gerenciamento Verde Editora, Brasilia, Brazil.

Nickerson, C.J., M. Morehart, T. Kuethe, J. Beckman, J. Ifft, and R. Williams. 2012. Trends in US farmland values and ownership. USDA Economic Research Service. http://www.ers.usda.gov/ media/377487/eib92_2_.pdf (accessed December 10, 2012).

Nixon, R. 2014. E.P.A.'s Proposed Rules on Water Worry Farmers. New York Times. 05/12/2014. http://www.nytimes.com/2014/03/13/us/politics/environmental-protection-agency-water-rules. html (accessed October 29, 2014).

O’Donoghue, E.J., R.A. Hoppe, D.E. Banker, R. Ebel, K. Fuglie, P. Korb, M. Livingtston, C. Nickerson, and C. Sandretto. 2011. Economic information nulletin number 88: The changing organization of US farming. Washington, DC: USDA Economic Research Service.

Ofstehage, A. 2011. Nusta Juira's gift of Quinoa: Peasants, trademarks, and intermediaries in the transformation of a Bolivian commodity economy. Anthropology of Work Review 32, no. 2 : $103-14$.

Ofstehage, A. 2012. The construction of an alternative quinoa economy: Balancing solidarity, household needs, and profit in San Agustín, Bolivia. Agriculture and Human Values 29, no. 4: 441-54.

Oliveira, G. de L.T. 2013. Land regularization in Brazil and the global land grab. Development and Change 44, no. 2: 261-83. 
Peine, E. 2009. The Private State of Agribusiness: Brazilian Soy on the Frontier of a New Food Regime. PhD diss. Cornell University.

Peine, E. 2010. Corporate mobilization on the Soybean frontier of Mato Grosso, Brazil. In Contesting development: Critical struggles for social change, ed. P. McMichael, 132-46. New York: Routledge.

Polanyi, K. 2001. The great transformation. 2nd ed. Boston: Beacon Press.

Reboratti, C. 2010. Un mar de soja: la nueva agricultura en Argentina y sus consecuencias. Revista de Geografía Norte Grande no. 45: 63-76.

Sauer, S. 2012. Land and territory: Meanings of land between modernity and tradition. Agrarian South: Journal of Political Economy 1, no. 1: 85-107.

Scott, J.C. 1985. Weapons of the weak: Everyday forms of peasant resistance. Bethany, CT: Yale University Press.

Teubal, M. 2006. Expansión del Modelo Sojero en la Argentina: De la Produccion de Alimentos a los Commodities. Realidad Economica, 220(mayo/junio), 71-96.

USDA, National Agricultural Statistics Service. 2013. Acreage (June 2013). Washington, DC: USDAo. http://www.usda.gov/nass/PUBS/TODAYRPT/acrg0612.pdf (accessed July 15, 2013).

Valdivia, G. 2010. Agrarian capitalism and struggles over hegemony in the bolivian lowlands. Latin American Perspectives 37, no. 4: 67-87.

Warnken, P.F. 1999. The development and growth of the soybean industry in Brazil. Ames: Iowa State University Press.

Wolford, W. 2008. Environmental justice and agricultural development in the Brazilian Cerrado. In Environmental Justice in Latin America: Problems, Promise, and Practice, ed. David Carruthers, 213-38. Cambridge, MA: MIT Press.

Andrew Ofstehage earned a BS in agronomy from South Dakota State University and an MSc in management of agro-ecological knowledge and social change from Wageningen University. His master's thesis, The gift of the middleman, is a study of agrarian change, social relations and value transformation in relation to quinoa commodification in Bolivia. He is a $\mathrm{PhD}$ candidate in anthropology at the University of North Carolina at Chapel Hill, and a Fulbright Scholar. Email: aofste@live. unc.edu 